\title{
Pengaruh Kepemimpinan dan Motivasi terhadap Loyalitas Perawat Rumah Sakit Swasta Tipe B di Kota Bandung
}

\author{
Depera Kitriawaty ${ }^{1}$, Elsa Pudji Setiawati², Suryana Sumantri ${ }^{3}$ \\ ${ }^{1}$ Dinas Kesehatan Kabupaten Garut \\ ${ }^{2}$ Departemen Ilmu Kesehatan Masyarakat, Fakultas Kedokteran Universitas Padjadjaran \\ ${ }^{3}$ Program Studi Doktor, Fakultas Psikologi Universitas Padjadjaran
}

\begin{abstract}
Abstrak
Permasalahan penting yang dihadapi oleh pimpinan di rumah sakit adalah bagaimana dapat mempertahankan loyalitas sehingga dapat mendukung keberhasilan pencapaian tujuan. Rumah sakit berupaya mempertahankan pegawai bermutu agar bekerja dalam jangka waktu lama di rumah sakit merupakan salah satu tujuan rumah sakit. Namun, kenyataannya di Tahun 2015 tercatat $11,47 \%$ pegawai diantaranya $8,50 \%$ perawat yang mengundurkan diri karena berbagai alasan. Penelitian ini bertujuan untuk menganalisis pengaruh kepemimpinan dan motivasi terhadap loyalitas. Metode penelitian menggunakan pendekatan survey analitik cross sectional. Sampel penelitian diambil dari perawat rawat inap sebanyak 90 orang dengan pengambilan sampel acak sistematik. Analisis data melalui tiga tahap, yaitu univariat, bivariat dan multivariat. Hasil penelitian dengan regresi linier berganda kepemimpinan bernilai positif menunjukan adanya hubungan searah antara kepemimpinan dengan loyalitas, maka setiap peningkatan kepemimpinan menyebabkan meningkatnya loyalitas perawat. Motivasi bernilai positif menunjukkan adanya hubungan searah antara motivasi dengan loyalitas, maka untuk setiap peningkatan motivasi menyebabkan meningkatnya loyalitas perawat. Pembahasan hasil penelitian bahwakepemimpinan dan motivasiberpengaruh positif terhadaployalitas perawat.Kepemimpinandanmotivasidapatdijadikanaspekyangdiperhitungkandalampengelolaan rumah sakit untuk mewujudkan loyalitas sumber daya manusia yang tinggi dan mendukung ke arah peningkatan kualitas pelayanan rumah sakit agar memenuhi kebutuhan masyarakat sesuai dengan visi dan misi rumah sakit.
\end{abstract}

Kata Kunci : Cross sectional, Kepemimpinan, Loyalitas, Motivasi

\section{The Influence of Leadership and Motivaion Toward Nurse Loyalty of Private Hospital Type B in Bandung City}

\author{
Abstract
}

The most problem faced by leader in hospital is how to maintain the loyalty so can support the successful achievement of objectives. The hospital effort to maintain qualified employees to work at the hospital for a long time. It's one of hospital aim. However in fact on 2015 registered as much 11,47\% employees among others $8,50 \%$ employees resigned cause of many reasons. This research porpose to analyze the influence of leadership and motivation to loyalty. The research methode use survey analitic cross sectional approach. The sample are nurse-patien 90 person taken by systematic random sampling. Data analysis throught three stage, are univariat, bivariat, and multivariat. The result of research by multiple linier regression, the leadership is positif, it shows the unidirectional relationship between leadership and loyalty. So every increased leadership cause the increased loyalty employees. The motivation is positif, it shows the unidirectional relationship between motivation and loyalty. So every increased motivation cause the increased loyalty employees. The explanation of this research is the leadership and motivation positive influented to the loyalty employees. The leadership and motivation could be the important aspects in the hospital management to make real the right human resource loyalty and to support the increase hospital service quality so it can fullfill people need as same as hospital vission and mission.

Keyword : Cross sectional, Leadership, Loyality, Motivation

\footnotetext{
Korespondensi:

Depera Kitriawaty, SKM., MKM

Dinas Kesehatan Kabupaten Garut

Jl. Proklamasi No.7 Garut 44151

Mobile : 082120616111

Email : kitriawaty@gmail.com
} 


\section{Pendahuluan}

Rumah sakit sebagai salah satu fasilitas pelayanan kesehatan merupakan bagian sumber daya kesehatan yang sangat diperlukan dalam mendukung penyelenggaraan upaya kesehatan. Penyelenggaraan pelayanan kesehatan di Rumah Sakit mempunyai karakteristik dan organisasi yang sangat kompleks. Berbagai jenis tenaga kesehatan dengan perangkat keilmuannya masing-masing berinteraksi satu sama lain. Ilmu pengetahuan dan teknologi kedokteran yang berkembang sangat pesat yang harus diikuti oleh tenaga kesehatan dalam rangka pemberian pelayanan bermutu, membuat semakin kompleksnya permasalahan dalam Rumah Sakit. ${ }^{1}$

Tenaga kesehatan memiliki peranan penting untuk meningkatkan kualitas pelayanan kesehatan yang maksimal kepada masyarakat agar masyarakat mampu untuk meningkatkan kesadaran, kemauan, dan kemampuan hidup sehat sehingga akan terwujud derajat kesehatan yang setinggi-tingginya sebagai investasi bagi pembangunan sumber daya manusia. ${ }^{2}$

Salah satu investasi dalam pembangunan sumber daya manusia adalah melalui peningkatan kualitas sumber daya manusia mencakup kepemimpinan (leading) kegiatan unsur pimpinan agar pegawainya bertindak, mengambil keputusan, komunikasi ke bawahan, memberi dorongan, semangat dan inspirasi (motivasi), mengubah anggota kelompok kerja pegawai dan meningkatkan keterampilan kerja pegawai. ${ }^{3}$

Selain kepemimpinan terdapat juga motivasi dimana kegiatan untuk mempersatukan kepentingan perusahaan/rumah sakit dan kebutuhan pegawai, agar tercipta kerja sama yang serasi dan saling menguntungkan. Untuk mempengaruhi sikap dan perilaku pegawai kepada yang diinginkan, sumber daya manusia harus memahami sifat dan motif apa yang mendorong mereka mau bekerja di rumah sakit. Pada umumnya orang mau bekerja karena didorong keinginan untuk dapat memenuhi kebutuhan fisik dan rohaninya. Manajemen sumber daya manusia dalam melaksanakan motivasi harus berdasarkan kepada prinsip dan cara yang selama ini dikenal dengan pendekatan motivasi (motivation) berupa pemberian upah yang adil dan layak, kesempatan untuk maju/promosi, pengakuan sebagai individu, keamanan kerja, tempat kerja yang baik/kondisi kerja, penerimaan oleh kelompok/kelompok kerja, perlakuan yang wajar, dan pengakuan atas prestasi. ${ }^{5}$

Permasalahan penting yang dihadapi oleh pimpinan di rumah sakit adalah bagaimana dapat mempertahankan loyalitas sehingga dapat mendukung keberhasilan pencapaian tujuan.
Permasalahan loyalitas erat kaitannya dengan bagaimana kepemimpinan dan motivasi agar pegawai bekerja secara optimal sehingga dapat mendukung pencapaian tujuan visi misi rumah sakit. ${ }^{4}$

Berdasarkan teori loyalitas yang diungkapkan oleh Steers \& Porter (1983), yang menyatakan bahwa pertama, loyalitas kepada perusahaan sebagai sikap, yaitu sejauh mana seseorang pegawai mengidentifikasi tempat kerjanya yang ditunjukan dengan keinginan untuk bekerja dan berusaha sebaik-baiknya dan kedua, loyalitas terhadap perusahaan sebagai perilaku, yaitu proses dimana seseorang pegawai mengambil keputusan pasti untuk tidak keluar dari perusahaan. Loyalitas digunakan sebagai sarana untuk memikat dan mempertahankan pegawai dalam organisasi maupun perusahaan. Loyalitas pegawai merupakan sikap positif pegawai terhadap perusahaan tempat dia bekerja. Pegawai dengan sikap loyalitas yang tinggi dapat bekerja tidak hanya untuk dirinya sendiri tetapi juga untuk kepentingan perusahaan. ${ }^{7}$

Turnover sebagai akibat pegawai senior mengundurkan diri bukanlah keinginan rumah sakit, sebab kondisi ini membuat repot operasional rumah sakit. Sebaliknya, berupaya mempertahankan pegawai bermutu agar bekerja dalam jangka waktu lama di rumah sakit merupakan salah satu tujuan manajemen SDM rumah sakit. Namun, kenyataannya di Tahun 2015 tercatat $11,47 \%$ pegawai dan diantaranya $8,50 \%$ perawat yang mengundurkan diri karena berbagai alasan, seperti mengikuti keluarga pindah kota, berganti profesi, pindah bekerja ke rumah sakit lain, dan salah satu unsur penting yang menyebabkan pegawai mulai melirik ke rumah sakit lain adalah hilangnya perasaan pegawai sebagai bagian dari rumah sakit. Ikatan emosional yang lemah dengan rumah sakit menyebabkan pegawai mulai memikirkan alternatif bekerja di tempat lain. Jika tawaran di luar lebih menarik, pegawai jadi mudah tergoda. Namun, jika ikatan emosional antara pegawai dan rumah sakit demikian kuat, pegawai akan berat hati meninggalkan rumah sakit yang telah membesarkannya. ${ }^{4}$

\section{Metode}

Penelitian dilaksanakan di rumah sakit swasta tipe B di kota Bandung, karena merupakan salah satu dari rumah sakit swasta di kota Bandung yang memiliki Visi Unggul Terpercaya dan Islami. Waktu dimulai Oktober sampai dengan Nopember 2016. Metode penelitian dalam penelitian ini dirancang menggunakan metode penelitian 
survey analitik cross sectional pendekatan Cross Sectional (Potong Lintang). Survei analitik adalah survei atau penelitian yang mencoba menggali bagaimana dan mengapa fenomena kesehatan itu terjadi. Sampel penelitian diambil dari perawat rawat inap yang mewakili kualitas dan karakteristik sampel sebanyak 90 orang.

Kriteriainklusipadapenelitianini yaituperawat yang berstatus pegawai tetap dan pegawai tidak tetap, perawat yang tercatat sebagai pegawai di rumah sakit Al Islam Bandung. Kriteria eksklusi diantaranya adalah perawat yang terpilih namun sedang cuti lebih dari 5 (lima) hari kerja pada saat penelitian berlangsung dan perawat yang tidak bersedia ikut serta dalam penelitian. Pengambilan sampel acak sistematik (systematic sampling), dilakukan secara berurutan dengan interval tertentu. Teknik dalam memilih subjek yang diikutsertakan dalam penelitian ini berdasarkan nomor urut dari daftar nominatif perawat rawat inap yang ditempatkan di beberapa ruangan meliputi 11 (sebelas) ruangan diantaranya; Raudhah/VIP (Very Important Person) di lantai 1; ICU, perinatal, VK dan Nifas di lantai 2; HCU, Firdaus, Darussalam 3 dan Darussalam 3A di lantai 3; Darussalam 4 di lantai 4 dan Darussalam 5 di lantai 5. Selanjutnya diambil perawat sebanyak 10 sebagai subjek penelitian dengan nomor urut 1, 3, 5 dan seterusnya.

Analisis data menggunakan model Rasch (Rasch Measurement), data dalam bentuk equal dan interval ditampilkan dalam bentuk logit (logaritma odds digit) measure. Nilai logit measure inilah yang kemudian peneliti gunakan untuk analisis univariat, bivariat dan multivariat dengan uji statistik menggunakan Chi Square (X2) dan uji statistik regresi linier berganda (Multiple Linear Regression).

Pada penelitian ini, dalam pengambilan data dengan kuesioner, peneliti memperkenalkan diri dan memberikan penjelasan tentang tujuan penelitian, alasan mengapa subjek dipilih, risiko kerahasiaan data dan kompensasi dengan cara memberikan lembar informasi dan dijelaskan secara lisan. Setelah subjek memahami informasi tersebut maka subjek diminta untuk mengisi lembar Persetujuan Setelah Penjelasan (PSP). Untuk menghormati harkat dan martabat manusia, dalam penelitian ini responden juga diberikan hak untuk mengundurkan diri jika menghendaki.

\section{Hasil}

Hasil dalam penelitian ini adalah data hubungan pengaruh kepemimpinan dan motivasi terhadap loyalitas perawat rumah sakit Al Islam. Hasil analisis multivariat menggunakan regresi linier berganda (Multiple Linear Regression), ada beberapa uji asumsi klasik yang harus dipenuhi agar kesimpulan dari regresi tidak bias, yaitu uji normalitas, uji multikolinieritas, uji autokorelasi dan uji linieritas. Hasil uji normalitas dapat dilihat dari Grafik plot di bawah ini.



Gambar 1 Uji Normalitas

Uji normalitas dengan normal probability plot mensyaratkan bahwa penyebaran data harus berada di sekitar wilayah garis diagonal dan mengikuti arah garis diagonal. Berdasarkan grafik di atas dapat disimpulkan bahwa data dalam penelitian ini memenuhi syarat normal probability plot sehingga model regresi dalam penelitian ini memenuhi asumsi normalitas (berdistribusi normal), artinya data dalam penelitian ini berasal dari populasi yang berdistribusi normal.

Tabel 1 Uji Asumsi Klasik Loyalitas Perawat

\begin{tabular}{lccc}
\hline \multicolumn{1}{c}{ Variabel } & VIF & DW & $\begin{array}{c}\text { A N O V A } \\
\text { Sig. }\end{array}$ \\
\hline Kepemimpinan & 1,263 & 1,694 & 0,000 \\
Motivasi & 1,263 & & \\
\hline
\end{tabular}

Berdasarkan tabel 1 dapat dilihat bahwa nilai VIF yaitu 1,263 kurang dari 10 . Sehingga dapat disimpulkanbahwatidakterdapatmultikolinieritas dalam data penelitian ini, artinya bahwa antar variabel bebas kepemimpinan dan motivasi tidak saling mengganggu atau mempengaruhi.

Dengan jumlah sampel $n=90, \alpha=0,05$ dan banyaknya variabel independen $\mathrm{k}=2$, maka di dapat nilai kritis $\mathrm{dL}=1,6119$ dan $\mathrm{dU}=1,7026$. Hasil pengujian uji autokorelasi dalam penelitian ini berdasarkan tabel di atas dapat diketahui nilai Durbin watson sebesar 1,694. Sehingga nilai DW berada diantara dU $(1,7026)<$ DW $(1,694)<$ $4-d U(4-1,7026=2,2974)$. 
Maka dapat disimpulkan bahwa dalam penelitian ini tidak terdapat autokorelasi. Artinya bahwa variabel independen dalam penelitian ini tidak terganggu atau terpengaruhi oleh variabel penggangu. Berdasarkan tabel 1 dapat dilihat bahwa nilai signifikan tabel ANOVA sebesar 0,000 . Artinya nilai signifikan kurang dari 0,05 $(0,000<0,05)$ yang berarti bahwa hubungan bersifat linier. Hal ini menunjukan bahwa kepemimpinan dan motivasi berpola linier terhadap loyalitas perawat.

Analisis Regresi Berganda; Pengaruh kepemimpinan (X1) dan motivasi (X2) terhadap loyalitas $(\mathrm{Y})$ dapat dilihat dengan menggunakan analisis regresi linier berganda dengan persamaan sebagai berikut.

Loyalitas Perawat $(Y)=B 0+B 1 X 1+B 2 X 2+e$ Keterangan:

$$
\begin{array}{ll}
\mathrm{Y} & =\text { Loyalitas Perawat } \\
\mathrm{B} 0 & =\text { Konstanta } \\
\mathrm{B} 1, \mathrm{~B} 2 & =\text { Koefisien Regresi } \\
\mathrm{X} 1 & =\text { Kepemimpinan } \\
\mathrm{X} 2 & =\text { Motivasi } \\
\mathrm{e} & =\text { Error }
\end{array}
$$

Hasil pengolahan analisis regresi berganda dapat dilihat pada tabel di bawah ini.

Tabel 2 Analisis Regresi Berganda Loyalitas Perawat

\begin{tabular}{lcc}
\hline \multicolumn{1}{c}{ Varibael } & B & SE \\
\hline Konstanta & 0,475 & 0,172 \\
Kepemimpinan & 0,448 & 0,102 \\
Motivasi & 0,246 & 0,097 \\
\hline
\end{tabular}

Berdasarkan tabel 2 diperoleh persamaan regresi linier berganda sebagai berikut. Loyalitas Perawat $(\mathrm{Y})=0,475+0,448 \mathrm{X} 1+0,246 \mathrm{X} 2$

Dari persamaan regresi linier berganda di atas diperoleh nilai konstan sebesar 0,475. Artinya, jika variabel loyalitas perawat (Y) tidak dipengaruhi oleh kedua variabel bebasnya atau kepemimpinan (X1) dan motivasi (X2) bernilai nol, maka besarnya rata-rata loyalitas perawat bernilai 0,475 . Koefisien regresi untuk variabel bebas $\mathrm{X} 1$ (kepemimpinan) bernilai positif, menunjukkan adanya hubungan yang searah antara kepemimpinan (X1) dengan loyalitas perawat $(\mathrm{Y})$. Koefisien regresi variabel $\mathrm{X} 1$ sebesar 0,448 mengandung arti setiap peningkatan kepemimpinan (X1) sebesar satu satuan akan menyebabkan meningkatnya loyalitas perawat (Y) sebesar 0,448. Koefisien regresi untuk variabel bebas X2 (motivasi) bernilai positif, menunjukkan adanya hubungan yang searah antara motivasi (X2) dengan loyalitas perawat $(\mathrm{Y})$. Koefisien regresi variabel X2 sebesar 0,246 mengandung arti untuk setiap peningkatan motivasi (X2) sebesar satu satuan akan menyebabkan meningkatnya loyalitas perawat $(Y)$ sebesar 0,246 .

Analisis Korelasi; Analisis korelasi digunakan untuk mengetahui hubungan variabel independen (kepemimpinan dan motivasi) dengan variabel dependen (loyalitas perawat). Melalui analisis ini korelasi akan dicari pengaruh variabel independen terhadap variabel dependen (loyalitas perawat). Analisis korelasi diperoleh hasil analisis antara variabel independen (kepemimpinan dan motivasi) dengan variabel dependen (loyalitas perawat) sebagai berikut.

Tabel 3 Koefisien Korelasi dan Determinasi

\begin{tabular}{ccccc}
\hline Model & $\mathbf{R}$ & $\begin{array}{c}\mathbf{R} \\
\text { Square }\end{array}$ & $\begin{array}{c}\text { Adjusted } \\
\text { R Square }\end{array}$ & $\begin{array}{c}\text { Std. } \\
\text { of } \begin{array}{c}\text { Error } \\
\text { Estimate }\end{array}\end{array}$ \\
\hline 1 & $.584^{\mathrm{a}}$ & .341 & .326 & .408 \\
\hline
\end{tabular}

Berdasarkan tabel 3 dapat dilihat bahwa koefisien korelasi antara variabel independen dan dependen sebesar 0,584. Koefisien korelasi bertanda positif artinya korelasi yang terjadi antara variabel kepemimpinan dan moivasi terhadap loyalitas perawat adalah searah, dimana semakin besar kedua variabel independen maka akan diikuti oleh semakin besarnya variabel dependen. Nilai 0,584 , menunjukan korelasi yang terjadi antara variabel independen (kepemimpinan dan motivasi) dengan variabel dependen (loyalitas perawat) berada dalam kategori hubungan yang cukup kuat $(0,400-0,599)$. Koefisien determinasi pada intinya mengukur seberapa jauh kemampuan model dalam menerangkan variasi variabel. Koefisien determinasi ini digunakan karena dapat menjelaskan kebaikan dari model regresi dalam variabel dependen. Semakin tinggi nilai koefisien determinasi maka akan semakin baik pula kemampuan variabel independen dalam menjelaskan variabel dependen. Nilai koefisien determinasi adalah antara 0 (nol) dan 1 (satu). Nilai R2 yang kecil berarti kempuan variabel-variabel independen dalam menjelaskan variasi variabel dependen amat terbatas. Nilai yang mendekati 1 (satu) berarti variabel-variabel independen memberikan hampir semua informasi yang dibutuhkan untuk memprediksikan variasi variabel dependen.

Dari hasil outputspss pada tabel 3 dapat dilihat bahwa nilai koefisien determinasi atau R Square sebesar 0,341 atau $34,1 \%$. Hal ini menunjukan bahwa variabel yang diteliti (kepemimpinan dan motivasi) memberikan pengaruh terhadap loyalitas perawat sebesar 34,1, sedangkan sisanya dipengaruhi variabel yang tidak diteliti (variabel pengganggu).

Pengujian Hipotesis; Untuk mengetahui 
signifikan pengaruh variabel-variabel bebas secara bersama-sama atas suatu variabel terikat digunakan uji F. Hasil pengujian hipotesis secara simultan dapat dilihat pada tabel 4 .

Berdasarkan tabel 4 nilai F-hitung sebesar 22,544. Adapun nilai F-tabel pada tingkat signifikansi $5 \%$ dan degree of freedom (df) sebesar $\mathrm{k}=2$ dan derajat bebas penyebut $(\mathrm{df} 2)$ sebesar $\mathrm{n}-\mathrm{k}-1(90-2-1=87)$ adalah sebesar 3,10 . Jika kedua nilai ini dibandingkan maka nilai F-hitung lebih besar dari F-tabel $(22,544>$ 3,10 . Dengan hasil perbandingan 22,544 $>3,10$ (Fhitung > F-tabel) sehingga Ho ditolak. Dengan demikian dapat disimpulkan bahwa secara simultan variabel independen (kepemimpinan dan motivasi) memiliki pengaruh yang signifikan terhadap variabel dependen (loyalitas perawat).

Untuk mengetahui variabel yang berpengaruh signifikan secara parsial dilakukan pengujian koefisien regresi dengan menggunakan statistik Uji t. Penentuan hasil pengujian (penerimaan/ penolakan H0) dapat dilakukan dengan membandingkan t-hitung dengan t-tabel atau juga dapat dilihat dari nilai signifikansinya. Hasil pengujian hipotesis secara parsial dapat dilihat pada tabel 5 .

Berdasarkan tabel 5 dapat kita lihat nilai t-tabel yang diperoleh setiap variabel. Untuk membuat kesimpulan menerima atau menolak Ho, terlebih dahulu harus ditentukan nilai t-tabel yang akan digunakan. Nilai ini bergantung pada besarnya degree of freeedom (df) dan tingkat signifikansi yang digunakan. Dengan menggunakan tingkat signifikansi $5 \%$ dan nilai df sebesar $\mathrm{n}-\mathrm{k}-1(90-2-1=87)$ diperoleh nilai t-tabel sebesar 1,66256. Hasil pengujian pengaruh setiap variabel independen (kepemimpinan dan motivasi) terhadap variabel dependen (loyalitas perawat) adalah sebagi berikut.

Pengaruh Kepemimpinan Terhadap Loyalitas Perawat; Berdasarkan tabel 5 diketahui nilai t-hitung sebesar 4.373. Jika dibandingkan dengan nilai t-tabel sebesar 1,66256 maka t-hitung yang diperoleh jauh lebih besar dari nilai t-tabel, sehingga Ho ditolak. Dengan demikian dapat disimpulkan bahwa variabel kepemimpinan berpengaruh secara signifikan terhadap loyalitas perawat.

Pengaruh Motivasi Terhadap loyalitas perawat; Berdasarkan tabel 5 diketahui nilai t-hitung sebesar 2,540. Jika dibandingkan dengan nilai t-tabel sebesar 1,66256 maka t-hitung yang diperoleh jauh lebih besar dari nilai t-tabel. Sehingga Ho ditolak. Dengan demikian dapat disimpulkan bahwa variabel motivasi berpengaruh secara signifikan terhadap loyalitas perawat.

\section{Pembahasan}

Rumah Sakit Al Islam Bandung dalam perkembangannya semakin menunjukkan kemajuan yang cukup pesat dilihat dari kualitas dan kuantitas operasional pelayanannya, hal ini ditunjang oleh sistem manajemen yang mendukung ke arah perkembangan yang positif. Kepemimpinan dan motivasi menjadi aspek yang diperhitungkan dalam pengelolaan Rumah Sakit Al Islam Bandung untuk dapat mewujudkan produktivitas dan loyalitas sumber daya manusia yang tinggi dan mendukung ke arah peningkatan kualitas pelayanan Rumah Sakit Al Islam Bandung untuk memenuhi kebutuhan masyarakat sesuai dengan visi dan misinya.

Kepemimpinan dan motivasi Rumah Sakit

Tabel 4 Uji Hipotesis Secara Simultan

\begin{tabular}{lccccc}
\hline \multicolumn{1}{c}{ Model } & Sum of Squares & Df & Mean Square & F & Sig. \\
\hline Regression & 7.494 & 2 & 3.747 & 22.544 & $.000 \mathrm{~b}$ \\
Residual & 14.461 & 87 & .166 & & \\
Total & 21.956 & 89 & & & \\
\hline
\end{tabular}

Tabel 5 Uji Hipotesis Secara Parsial

\begin{tabular}{lccccc}
\hline \multirow{2}{*}{ Model } & \multicolumn{2}{c}{ Unstandardized Coefficients } & $\begin{array}{c}\text { Standardized } \\
\text { Coefficients }\end{array}$ & \multirow{2}{*}{ T } & Sig. \\
\cline { 2 - 4 } & $\mathrm{B}$ & $\mathrm{SE}$ & $\mathrm{Beta}$ & & .009 \\
\hline (Constant) & .457 & .172 & & 2.652 & .000 \\
Kepemimpinan & .448 & .102 & .428 & 4.373 & .013 \\
Motivasi & .246 & .097 & .248 & 2.540 & \\
\hline
\end{tabular}


Al Islam Bandung memfokuskan mengenai pengaturan peranan manusia dalam mewujudkan tujuan yang optimal. Pengaturan itu salah satunya adalah motivasi yang berperan sebagai fungsi manajemen sumber daya manusia untuk membantu terwujudnya tujuan rumah sakit, perawat dan masyarakat. Hasibuan (2005:23) "motivasi adalah kegiatan untuk mempersatukan kepentingan perusahaan dan kebutuhan perawat, agar tercipta kerja sama yang serasi dan saling menguntungkan".

Perawat tidak dapat diperlakukan seperti menggunakan faktor-faktor produksi lainnya (mesin, modal dan bahan baku). Perawat juga harus selalu diikutsertakan dalam setiap kegiatan serta memberikan peran aktif untuk menggunakan alat-alat yang ada karena tanpa peran aktif perawat, alat-alat canggih yang dimiliki tidak ada artinya bagi perusahaan untuk mencapai tujuannya. Tujuan rumah sakit hanya dapat dicapai jika para perawat bergairah bekerja, mengerahkan kemampuannya dalam menyelesaikan pekerjaan, serta berkeinginan untuk mencapai prestasi kerja yang optimal. Jika perawat kurang berprestasi maka sulit bagi organisasi rumah sakit dapat memperoleh hasil yang baik. Hal ini mengharuskan pemimpin menggunakan kewenangannya untuk mengubah sikap dan perilaku perawat supaya mau bekerja giat serta berkeinginan mencapai hasil yang optimal.

Upaya mempengaruhi sikap dan perilaku perawat kepada yang diinginkan, rumah sakit harus memahami sifat dan motif apa yang mendorong mereka mau bekerja pada Rumah Sakit Al Islam Bandung. Pada umumnya orang mau bekerja karena didorong keinginan untuk dapat memenuhi kebutuhan fisik dan rohaninya. Jadi rumah sakit harus berusaha memberikan balas jasa yang adil dan layak, serta memperlakukan perawat dengan baik sebagaimana layaknya manusia. Perawat juga harus menyadari mengapa rumah sakit menerima mereka dan apa yang diharapkan dari perawat. Rumah sakit selalu mengharapkan agar perawatnya bekerja giat, mematuhi disiplin, serta merealisasikan prestasi kerja yang baik, karena hanya dengan cara ini rumah sakit dapat memperoleh keuntungan.

Motivasi menjadi penting karena motivasi adalah hal yang menyebabkan, menyalurkan, dan mendukung perilaku manusia, supaya mau bekerja giat dan antusias mencapai hasil yang optimal. Motivasi semakin penting karena manajemen sumber daya rumah sakit membagikan pekerjaan pada bawahannya untuk dikerjakan dengan baik dan terintegrasi kepada tujuan yang diinginkan. Rumah sakit bukan saja mengharapkan perawat mampu, cakap dan terampil, tetapi yang terpenting mereka mau bekerja giat dan berkeinginan untuk mencapai hasil kerja yang maksimal. Kemampuan dan kecakapan perawat tidak ada artinya bagi rumah sakit jika mereka tidak mau bekerja giat.

Kesungguhan para perawat tampak dalam komitmen mereka terhadap rumah sakit. Lebih jauh, komitmen perawat terhadap rumah sakit ditunjukan melalui kesetiaan dan loyalitas. Seperti diungkapkan Mowday dan Steers (1979, dalam Istijanto, 2006:205), komitmen merupakan loyalitas perawat terhadap suatu unit sosial yang bisa berupa loyalitas perawat terhadap perusahaan, departemen, atau terhadap pekerjaan mereka.

Perawat yang memiliki loyalitas tinggi bersedia bekerja melebihi kondisi biasa, bangga menceritakan rumah sakit mereka kepada orang lain, bersedia menerima berbagai tugas, merasa ada kesamaan nilai dengan organisasi rumah sakit, merasa terinspirasi dan memperhatikan nasib organisasi rumah sakit secara keseluruhan. Sebaliknya, perawat yang tidak setia terhadap rumah sakit ditandai dengan perasaan negatif, seperti ingin meninggalkan rumah sakit, merasa bekerja di rumah sakit lain lebih menguntungkan, tidak merasakan manfaat dari rumah sakit dan menyesali keputusan mereka bergabung dengan rumah sakit.

Penelitian ini telah memberikan gambaran baik secara simultan maupun parsial (multivariat) pada tingkat kepercayaan $95 \%$ diketahui secara simultan kepemimpinan dan motivasi memiliki pengaruh yang signifikan terhadap loyalitas perawat. Hal ini berarti loyalitas perawat akan sangatdipengaruhiolehbagaimana RSAIBandung memberikan dan menerapkan kepemimpinan dan motivasi terhadap seluruh perawat di Rumah Sakit Al Islam Bandung. Komitmen perawat terhadap rumah sakit ditunjukan melalui kesetiaan dan loyalitas. Perawat dengan sungguh-sungguh memberikan usaha terbaik demi kemajuan rumah sakit. Perawat yang memiliki loyalitas tinggi bersedia bekerja melebihi kondisi biasa, bangga menceritakan perusahaan mereka kepada orang lain, bersedia menerima berbagai tugas, merasa ada kesamaan nilai dengan rumah sakit, merasa terinspirasi, dan memperhatikan nasib RSAI Bandung.

Kesimpulan, kepemimpinan dan motivasi berpengaruh positif terhadap loyalitas perawat. Kepemimpinan bernilai positif menunjukan adanya hubungan yang searah antara kepemimpinan dengan loyalitas, maka setiap peningkatan kepemimpinan akan menyebabkan meningkatnya loyalitas perawat. Motivasi bernilai positif menunjukkan adanya hubungan yang searah antara motivasi dengan loyalitas, 
maka untuk setiap peningkatan motivasi akan menyebabkan meningkatnya loyalitas perawat.

Saran, perlunya pengembangan dan kajian mengenai kepemimpinan dan motivasi sebagai upaya menambah khasanah keilmuan manajemen sumber daya manusia dan perlunya penelitian lain berkaitan dengan loyalitas perawat di instansi rumah sakit/pelayanan kesehatan, sehingga lebih banyak rujukan hasil penelitian yang dapat dimanfaatkan untuk peningkatan sumber daya manusia kesehatan.

Rumah sakit harus mampu memahami sifat dan motif apa yang mendorong perawat mau bekerja giat dan berkeinginan untuk mencapai hasil kerja yang maksimal di Rumah Sakit Al Islam Bandung. Kepemimpinan dan motivasi dapat dijadikan aspek yang diperhitungkan dalam pengelolaan Rumah Sakit Al Islam Bandung untuk dapat mewujudkan loyalitas sumber daya manusia yang tinggi dan mendukung ke arah peningkatan kualitas pelayanan Rumah Sakit Al Islam Bandung untuk memenuhi kebutuhan masyarakat sesuai dengan visi dan misinya.

\section{Daftar Pustaka}

1. Undang Undang. Rumah Sakit. 2009: 44-23.

2. Undang Undang Republik Indonesia. Tenaga Kesehatan. 2014: 36-1.

3. Rita Ivana Ariyani. Pengaruh Gaya Kepemimpinan Dan Loyalitas Pegawai Terhadap Kinerja Karyawan Di Rumah Sakit Islam Hidayatullah Yogyakarta. Jurnal Medicoeticoilegal dan Manajemen Rumah Sakit. 2016;5(2).

4. Hasibuan SP Malayu. Manajemen Sumber Daya Manusia. Jakarta: Bumi Aksara. 2005:7h hlm. 141, 143, 144-145, 146, 148, 149.

5. RSAI Bandung. Profil Rumah Sakit Al Islam Bandung. 2014-2019.

6. Aityan, S.K. dan Gupta. Challenges of Employee Loyalty in Corporate America. Journal Research Article, Accepted Version. 2011. 2 (2). pp 47-54.
7. Abdullah, R., Musa, M., Zahari, H. dan Rahman, R. The Study of Employee Satisfaction, Workplace and Communication to Wards Loyalty in Hotel Industry in Klang Valley Malaysia. International Journal of Business and Social Science. 2011. 2 (3). pp: $147-155$.

8. Evawati. Pengaruh Budaya Organisasi Terhadap Loyalitas Perawat Bagian Anak Rumah Sakit Umum Daerah Tanggerang. Jurnal Ilmu Ekonomi dan Sosial. 2013. 1 (3). pp: $233-355$

9. Omar, M.W., Kamaruzaman, J. dan Harniyati, H. Employee Motivation, Workplace and its Impact on Employee Loyalty. World Applied Sciences Journal. 2010. 8 (7). pp: 871 - 873.

10. Akhsanu Ridlo I. Turn Over Karyawan. Surabaya. Public Health Movement. 2012.

11. Jati Sasmito. Pengaruh Kepemimpinan Karismatik Terhadap Loyalitas Karyawan dan Harga Diri Pada Perusahaan Multifinance Di Sragen. Pascasarjana Universitas Muhammadiyah Surakarta. Surakarta. 2014.

12. Istijanto. Riset Sumber Daya Manusia. Cetakan Kedua. Jakarta: Gramedia Pustaka Utama. 2006.

13. Sugiyono. Metode Penelitian Kuantitatif Kualitatif dan R\&D. Bandung: Alfabeta. 2011: hlm. 38-41, 81

14. Budiarto Eko. Metodologi Penelitian Kedokteran. Jakarta: EGC. 2006: 37.

15. Riduwan. Belajar Mudah Penelitian Untuk Guru, Karyawan dan Peneliti Pemula. Bandung: Alfabeta. 2015.

16. Sumintono B., Widhiarso W., Aplikasi Pemodelan Rasch Pada Assessment Pendidikan. Cimahi: Trim Komunikata Publishing House; 2015. hlm.70.

17. Sumintono B., Widhiarso W., Aplikasi Model rasch untuk Penelitian IlmuIlmu Sosial. Edisi Revisi. Cimahi : Trim Komunikata Publishing House; 2015. hlm.54, 55, 60, 71.

18. Hastono. Statistik Kesehatan. Jakarta: Raja Grafindo Persada. 2011: hlm. 68-86, 115127. 